\title{
A CERTIDÃo de CRÉDITO TRABALHISTA E O ACESSO À INJUSTIÇA: CELERIDADE SEM EFETIVIDADE.
}

\section{THE CERTIFICATE OF LABOR CREDIT AND THE ACCESS TO INJUSTICE. CELERITY INEFFECTIVE.}

Lamartino França de Oliveira $^{1}$

\section{Resumo}

Este artigo foi concebido a partir da ciência da criação pretoriana da certidão de crédito trabalhista. Consiste ela em um documento formal emitido por diversos tribunais do trabalho certificando que determinada pessoa possui crédito em um processo trabalhista, cuja execução encontra-se inefetiva. Entregue a certidão ao credor o processo que a originou é arquivado definitivamente. Materializa-se, assim, o acesso à injustiça. A doutrina e a academia ainda não se debruçaram sobre este tema. Não se justifica este silêncio. Para quebrá-lo, buscou-se suporte nos fundamentos do processo, na legislação vigente e jurisprudência atual. Para tanto, foram utilizados argumentos que atestam a inconstitucionalidade, a ilegalidade e os prejuízos que a expedição da certidão de crédito pode gerar ao credor trabalhista. Conclui-se que a sua adoção poderá contribuir para fomentar o descrédito do judiciário laboral junto aos jurisdicionados pela possibilidade de ser aplicada a então esquecida prescrição da pretensão executiva no processo do trabalho. Ao final, de forma propositiva, apresentam-se algumas soluções viáveis que impediriam a expedição da certidão de crédito e o acesso à injustiça.

Palavras-chave: Tribunais do Trabalho. Certidão de crédito. Ilegalidade. Inefetividade.

\section{INTRODUÇÃO}

A Constituição Federal de 1988 dispõe em seu art. 5, inciso XXXV, que "a lei não excluirá da apreciação do Poder Judiciário qualquer lesão ou ameaça a direito" (BRASIL, 2011a,). Garante tal dispositivo o direito fundamental de acesso à justiça. Esse acesso não se limita a reconhecer o direito a um provimento jurisdicional, mas à tutela eficaz e efetiva.

A sociedade hodierna pode ser identificada pela pressa e pela falta de tempo. Por esta ótica, garantir o acesso a uma justiça eficaz e efetiva já não basta. Tornou-se necessário preocupar-se com o tempo do processo.

A fim de evitar que o acesso à justiça se convole em injustiça pela demora do processo, a Emenda Constitucional $n^{\circ} 45 / 2004$ inseriu o inciso LXXVIII ao art. $5^{\circ}$ da Constituição Federal, para assegurar ao jurisdicionado a "duração razoável do processo e os meios que garantam a celeridade de sua tramitação." (BRASIL, 2004).

1 Mestrando em Direito do Trabalho pela PUC-MG; Juiz do Trabalho - Titular da Vara do Trabalho de Nova Mutum-MT; Professor da Escola Judicial do TRT da $23^{\text {a }}$ Região.

Revista da Faculdade Mineira de Direito, v.12, n. 23, jan./jun. 2009 - ISSN 1808-9429. 38 
Para planejar, organizar, coordenar, controlar, supervisionar e aperfeiçoar a atividade de prestação de justiça foi criado, na mesma Emenda Constitucional referida, o Conselho Nacional de Justiça - CNJ. Instalado em 14 de junho de 2005, este órgão integra o Poder Judiciário, conforme art. 92, I-A, da Constituição Federal.

Ao CNJ coube traçar as diretrizes para se cumprir o inciso LXXVIII, do artigo $5^{\circ}$, da Constituição Federal. Para tanto, dentre outras medidas adotadas, estabeleceu metas anuais a serem cumpridas pelos diversos tribunais do país. O escopo almejado era reduzir o número de processos em trâmite no Judiciário. (Conselho Nacional de Justiça, 2010)

Premidos pelas metas do $\mathrm{CNJ}$, vários Tribunais do Trabalho criaram artifícios procedimentais específicos para a extinção da execução trabalhista. Dentre estes, destaca-se a figura da certidão de crédito. Trata-se de um documento expedido pelas Varas do Trabalho que certifica que determinada pessoa possui crédito em um processo trabalhista, cuja execução encontra-se inefetiva. Entregue a certidão, o processo que a originou é arquivado definitivamente com a chancela processo resolvido. Desta forma, o processo foi utilizado não como um instrumento da jurisdição, mas como um fim em si mesmo. Materializa-se, assim, o acesso à injustiça.

Apesar desta constatação negativa, com efeito, nota-se que doutrina e academia ainda não editaram nenhuma linha sobre os efeitos processuais e materiais desta criação pretoriana. Não se justifica este silêncio. Para quebrá-lo, este artigo buscará teorizar o tema a partir do ensinamento de Eduardo J. Couture (1942) sobre a efetividade do direito por intermédio da jurisdição, buscando suporte na legislação vigente e jurisprudência atual.

O objetivo é demonstrar que em nome da celeridade processual não se deve vitimar o direito. $\mathrm{O}$ tempo do processo deve ser o necessário para a efetiva entrega do bem da vida. Celeridade na medida da efetividade. Para atingir este escopo serão utilizados argumentos que atestam a inconstitucionalidade, a ilegalidade e os efeitos nefastos que a expedição da certidão de crédito pode gerar ao credor trabalhista.

Ao final, de forma propositiva, serão apresentadas outras medidas executivas que poderiam ser utilizadas pelos Juízes do Trabalho como forma de evitar que o processo torne um fim em si mesmo. 


\title{
2. DA ORIGEM DA CERTIDÃO DE CRÉDITO TRABALHISTA
}

O primeiro órgão jurisdicional que instituiu a expedição da certidão de crédito trabalhista foi o Tribunal Regional do Trabalho da $3^{\text {a }}$ Região - TRT03-, cuja jurisdição circunscreve-se ao Estado de Minas Gerais. Por intermédio do Provimento no 02/2004 ele criou a certidão da dívida trabalhista2, cuja denominação foi alterada em 2010 para certidão de dívida de qualquer natureza. Pela originalidade, transcreve-se parte da norma que criou à certidão:

\footnotetext{
Art. $1^{\circ}$ Promovida a execução pelo interessado, ou pelo Juiz ex officio, seu curso será suspenso, por um ano, se:

I - o devedor não for localizado;

II - não forem encontrados bens sobre os quais possa recair a penhora;

III - os bens penhorados não forem arrematados ou adjudicados.

Art. $2^{\circ}$ Suspenso o curso da execução, o credor será intimado para, naquele prazo, indicar os meios efetivos para o seu prosseguimento.

Art. $3^{\circ} \mathrm{O}$ processo será definitivamente arquivado depois de suspenso por um ano, caso em que será expedida e remetida ao credor certidão da dívida trabalhista (MINAS GERAIS, 2004)
}

O professor Luiz Otávio Linhares Renault em artigo sobre o tempo do processo, teceu suas impressões sobre esta novidade pretoriana:

\begin{abstract}
Da sua leitura, pelo menos para mim, fica a impressão de que a certidão da dívida trabalhista, expedida e remetida ao credor, tem por objetivo reduzir o número de processos na secretaria da vara, aumentando inclusive o espaço físico para a acomodação de novos processos, que chegam aos bortotões diariamente.

Uns partindo, outros chegando [...]

Temos aí a vida e a morte, repetindo seus enredos com os processos [...] o maior perdedor é o empregado [...] ao invés do recebimento do seu crédito, uma certidão para o Reclamante...

Indago [...] não seria isso o prenúncio de algo como as cinzas do processo? (RENAULT, 2006).
\end{abstract}

Respondendo à indagação acima, o próprio concluiu:

\begin{abstract}
Não podemos esquecer que, ao ser encaminhado (os autos do processo) para o arquivo central [...] passará por uma rápida triagem para verificação de seu valor histórico; ficará arquivado por certo tempo e depois incinerado. Sonho, alegria, satisfação, decepção e dor virando cinzas. (RENAULT, 2006).
\end{abstract}

Com a edição da Emenda Constitucional 45/2004 e a posterior criação do CNJ, coincidência ou não, fato é que diversos tribunais trabalhistas, copiaram o modelo do tribunal mineiro. Atualmente, 17 dos 24 tribunais do trabalho ${ }^{3}$ existentes no país

2 A denominação da certidão varia de tribunal para tribunal. A mais utilizada é certidão de crédito.

3 Tribunais do Trabalho que já adotaram a certidão de crédito, por região, em ordem crescente: $1^{\mathrm{a}}$-RJ, $2^{\mathrm{a}}$ SP, $3^{\mathrm{a}}-\mathrm{MG}, 5^{\mathrm{a}}-\mathrm{BA}, 6^{\mathrm{a}}-\mathrm{PE}, 7^{\mathrm{a}}-\mathrm{CE}, 8^{\mathrm{a}}-\mathrm{PA} / \mathrm{AP}, 10^{\mathrm{a}}-\mathrm{DF} / \mathrm{TO} .13^{\mathrm{a}}-\mathrm{PB}, 14^{\mathrm{a}}-\mathrm{RO} / \mathrm{AC}, 16^{\mathrm{a}}-\mathrm{MA}, 17^{\mathrm{a}}-\mathrm{ES}, 18^{\mathrm{a}}-$ GO, 19'-AL, 20 $0^{\mathrm{a}}-\mathrm{SE}, 21^{\mathrm{a}}-\mathrm{RN}$ e $23^{\mathrm{a}}-\mathrm{MT}$.

Revista da Faculdade Mineira de Direito, v.12, n. 23, jan./jun. 2009 - ISSN 1808-9429. 
adotaram a certidão de crédito como forma de extinção do processo trabalhista. Crê-se, como fê-lo Renault, que o objetivo destes tribunais é manifesto: retirar dos escaninhos das secretarias das varas a massa de processos que os entulham, para dar lugar à outra plêiade de feitos que estão na fila, aguardando espaço serem acomodados.

\subsection{Da Inconstitucionalidade formal}

Hans Kelsen (1998) elaborou os contornos do que se denominou ser o princípio da hierarquia das leis. Ensinou ele que entre uma norma de escalão superior e uma norma de escalão inferior não pode existir qualquer conflito, pois, a norma do escalão inferior tem o seu fundamento de validade na norma do escalão superior.

$\mathrm{Na}$ hierarquia das leis a Constituição Federal ocupa o ápice da pirâmide normativa. Logo, a partir deste cume é propagada a sua força vinculante às demais regras inferiores do arcabouço jurídico nacional.

O Direito Constitucional define a moldura dentro da qual o intérprete exercerá sua criatividade e seu senso de justiça, sem conceder-lhe, contudo, um mandato para voluntarismos de matizes variados. (BARROSO, 2005).

Em se tratando se competência legislativa, a Constituição Federal delineou os exatos contornos para a atuação dos legisladores futuros. Pelo disposto nos arts. 22, I e 24, XI, apenas a União possui competência para legislar sobre processo e procedimento.

Ainda, nos termos do art. 96, inciso I, alínea "a" da Constituição Federal, coube aos tribunais, privativamente, elaborar os próprios regimentos internos, com observância das normas de processo e das garantias processuais das partes, inclusive dispondo sobre a competência e o funcionamento de seus órgãos estruturantes.

A partir desta textura constitucional, verifica-se que o artigo 96, I, "a" da Constituição Federal, repetiu os ensinamentos de Hans Kelsen (1998) ao exigir que as normas internas dos tribunais obedecessem às regras do processo ditadas pelo legislador federal. Assim, a rigor, cabe ao Congresso Nacional, mas não aos tribunais, a edição de normas processuais e procedimentais.

Por este prisma, tem-se que todos os atos dos tribunais trabalhistas que tratam da certidão de crédito como forma de extinção da execução, com o consequente arquivamento definitivo e a incineração dos autos do processo, são inconstitucionais. Com efeito, a inconstitucionalidade formal destas normas processuais reside na falta de competência legislativa dos tribunais para criarem procedimentos que cuidem da 
extinção do processo. Trata-se, pois, de um voluntarismo pretoriano prejudicial aos interesses da efetividade da jurisdição.

\subsection{Da Dupla Ilegalidade}

A despeito da inconstitucionalidade formal mencionada no tópico precedente, as normas que criaram as certidões de crédito no âmbito dos tribunais do trabalho possuem ilegalidade formal dúplice.

A primeira ilegalidade que se constata reside no fato de que a Consolidação das Leis do Trabalho - CLT é silente quanto ao momento da extinção do processo na execução. Então, supletivamente, deve-se aplicar, nesta ordem, por força dos artigos 899 e 769 da CLT, a Lei 6.830/80 que trata da execução fiscal da Fazenda Pública e as regras executivas do Código de Processo Civil - CPC.

Da mesma forma que a CLT, a lei de executivos fiscais é omissa sobre a forma de extinção do processo na fase de execução. Dita norma apenas permite o arquivamento provisório (artigo $40, \S 2^{\circ}$ ) ou a pronúncia da prescrição intercorrente (artigo $40, \S 4^{\circ}$ ).

Resta, então, integrar à norma trabalhista as regras do CPC. Este diploma processual trata da matéria no art. 794 , verbis:

\footnotetext{
Art. 794. Extingue-se a execução quando:

I - o devedor satisfaz a obrigação;

II - o devedor obtém, por transação ou por qualquer outro meio, a remissão total da dívida;

III - o credor renunciar ao crédito. (BRASIL, 2008a).
}

Verifica-se por este dispositivo que o CPC nada dispõe sobre a extinção da execução mediante a entrega de certidão de crédito, quando se constata a falta de bens do devedor. Crê-se que essa opção sequer foi pensada pelo legislador, haja vista que tal direção faria com que o processo se tornasse um fim em si mesmo.

Neste sentido, Eduardo J. Couture (1942) já ensinava desde meados do século passado que:

O conteúdo da jurisdição não se reduz à atividade cognitiva, mas também a sua atividade executiva. Conhecimento e declaração sem execução é academia e não justiça; execução sem conhecimento é despotismo e não justiça. Só um perfeito equilíbrio entre as garantias do exame do caso e as possibilidades de fazer efetivo o resultado deste exame, dá à jurisdição seu efetivo sentido de realizadora da justiça [...] o fim da jurisdição é assegurar a efetividade do direito (COUTURE, 1942, p. (89, tradução livre) ${ }^{4}$

4 El contenido de la jurisdicción no se reduce a la actividad cognoscitiva de la misma sino también a su actividad ejecutiva. Conocimiento y declaración sin ejecución es academia y no justicia; ejecución sin

Revista da Faculdade Mineira de Direito, v.12, n. 23, jan./jun. 2009 - ISSN 1808-9429. 42 
$\mathrm{O}$ excerto do ensinamento supratranscrito mostra que o processo não pode existir para si, mas para a realização de um direito material afirmado como existente e do qual é dependente. Afinal, o objetivo-fim da jurisdição é assegurar o acesso à justiça para a efetivação do direito material controverso.

Por outro lado, diante da omissão da CLT e da Lei de executivos fiscais, o CPC já determinou qual deverá ser o caminho processual a ser seguido quando o executado não possuir ou não forem encontrados bens disponíveis para a penhora. Neste caso, por força do disposto no art. 791, inciso III, a execução deverá ser suspensa, mas não extinta.

Ainda, a ilegalidade do ato que emite a certidão de crédito é ampliada ao se notar que o artigo 793 do CPC veda a prática de quaisquer atos no processo, exceto as medidas cautelares urgentes, enquanto a execução estiver suspensa. A fortiori, estando a execução suspensa com o processo em arquivo provisório é vedado ao juiz extingui-lo, mediante entrega de certidão imprópria para o fim a que se destina.

A segunda ilegalidade é verificável ao serem ditas normativas dos tribunais confrontadas com o art. 798 da CLT. Por este dispositivo a execução pode ser promovida por qualquer interessado. De igual maneira, dispõe que ela se processará de ofício pelo Juiz ou Presidente do Tribunal competente.

Nestes termos, claro está que tanto a parte interessada quanto o juiz do trabalho possuem legitimação concorrente para promover a execução do crédito trabalhista.

Por este foco, não poderia ser expedida a certidão de crédito sob o argumento de que a inércia do autor em indicar bens passíveis de constrição judicial foi a causa da extinção da execução, conforme previsto em todos os textos dos tribunais que a instituíram, haja vista que, legalmente, não é o credor o único responsável pelo resultado útil do processo. A única exceção a esta regra surge quando a liquidação de sentença é por artigos, e o credor não apresenta meios para se procedê-la. Nesta hipótese, o juiz não pode arvorar-se no dever único e exclusivo da parte credora.

conocimiento es despotismo y no justicia. Sólo un perfecto equilibrio entre las garantías del examen del caso y las posibilidades de hacer efectivo el resultado de ese examen, da a la jurisdicción su efectivo sentido de realizadora de la justicia [...] el fin de la jurisdicción es garantizar la efectividad del derecho. (COUTURE, 1942, p. 89).

Revista da Faculdade Mineira de Direito, v.12, n. 23, jan./jun. 2009 - ISSN 1808-9429. 43 


\section{DOS EFEITOS NEGATIVOS DA CERTIDÃO DE CRÉDITO}

A falta de efetividade da execução trabalhista sempre foi um problema para a Justiça do Trabalho. Acredita-se que uma das causas deste é o fato de, historicamente, ter ela concentrado esforços para incrementar a celeridade na fase de conhecimento e a entabulação de conciliações, olvidando-se da fase executiva, momento processual em que a efetividade da jurisdição se realiza com a entrega do bem da vida ao jurisdicionado. Os dados estatísticos do TST, apontados no item 3.1, abaixo, comprovam esta realidade.

Cônscios desta realidade, alguns Tribunais do Trabalho criaram a figura processual da certidão de crédito, contudo, não observaram que ela resolve o problema do judiciário laboral com a extinção de inúmeros processos, todavia, é ineficaz em termos efetivos, na medida em que possui efeitos colaterais não pensados ou menosprezados pelos seus idealizadores. Ilustram-se alguns destes, nos itens que se seguem.

\subsection{O descrédito do judiciário trabalhista}

Os dados sobre a falta de efetividade da execução trabalhista são alarmantes, segundo o Ministro do Tribunal Superior do Trabalho - TST, João Orestes Dalazen. Conforme relatou em seu discurso de posse como presidente da mais alta corte trabalhista do país, em janeiro de 2011, os números estatísticos do TST apontam "que de cada 100 (cem) reclamantes que obtiveram ganho de causa, somente 31 (trinta e um) alcançaram êxito na cobrança de seu crédito". Isto é, 69\% dos processos da fase de execução não alcançam resultado útil. "Um processo que não proporcione ao credor a satisfação de seu direito leva à descrença na Justiça”. (DALAZEN, 2011)

A frase dita pelo Ministro Dalazen aponta o primeiro efeito negativo da expedição da certidão de crédito: o descrédito. Em nome da celeridade e de uma pseudo-efetividade processual os tribunais resolvem os seus problemas estatísticos, em detrimento da efetividade e credibilidade de suas decisões cognitivas. Produtividade e efetividade materializadas em uma certidão sem liquidez alguma.

Acredita-se que a solução para o problema não está na emissão da certidão de crédito, como quer fazer crer a maioria dos Tribunais do Trabalho. Se assim fosse, bastaria emitir certidões de crédito para os $69 \%$ dos exeqüentes que não obtiveram êxito na cobrança judicial do crédito trabalhista. 


\subsection{Da prescrição da pretensão executiva $x$ prescrição intercorrente}

O segundo e maior prejuízo direto para o exequente-trabalhador é a possibilidade de se pronunciar a prescrição da pretensão executiva.

O conceito de prescrição da pretensão executiva é inferível da própria locução adjetiva. Sobre a prescrição intercorrente, adota-se o conceito atribuído pelo Professor Vitor Salino de Moura Eça, que a definiu como:

O instituto de direito processual, que importa na ineficácia do exercício da pretensão em decorrência da inatividade do demandante em efetivar atos processuais de sua alçada exclusiva, por prazo superior ao que the foi consagrado para deduzir a pretensão em juízo. (EÇA, 2008, p. 49).

Conforme já destacado, nos termos do art. 878 da CLT, a parte interessada e o Juiz do Trabalho possuem legitimação concorrente para promover a execução trabalhista. Com base neste comando legal, o TST editou a Súmula 114, a qual dispõe que "não se aplica na Justiça do Trabalho a prescrição intercorrente” (BRASIL, 1980).

Cabe registrar que excepcionalmente, apesar da Súmula 114, o próprio TST tem admitido a prescrição intercorrente na hipótese em que o credor é omisso na prática de determinado ato que apenas a ele incumbia:

\footnotetext{
Não se confundem a prescrição da pretensão executiva com a prescrição intercorrente. Na primeira, o exequente não postula a sua instauração, no biênio posterior ao trânsito em julgado da decisão exequenda, enquanto, na segunda, excusa-se a parte de praticar ato que somente dela dependia. Recurso de revista conhecido e provido. (BRASIL, 2011b, grifo nosso).
}

Portanto, como regra geral, a fase de execução de sentença no processo do trabalho não é interrompida pela prescrição intercorrente.

Assim, com a emissão da certidão de crédito, os autos do processo que a gerou serão arquivados, e, após algum período, descartados ou incinerados. Fim do processo. Início do possível prejuízo do credor-trabalhista.

Extinto o processo originário com a expedição da certidão de crédito, o exequente poderá postular a sua pretensão em ação de execução autônoma. Tratando-se de um novo procedimento, haverá prazo prescricional para o ajuizamento desta ação de execução? Por enquanto, após intensa pesquisa, nada foi encontrado na doutrina e jurisprudência sobre o tema em específico.

Neste artigo, responde-se a esta indagação de forma positiva. 
De plano, desvela-se que não se trata mais de prescrição intercorrente, haja vista que não mais existirá nenhum procedimento judicial em trâmite depois da entrega da certidão ao credor.

Nos termos do artigo 580 do CPC a execução pode ser instaurada caso o devedor não satisfaça a obrigação certa, líquida e exigível, consubstanciada em título executivo. (BRASIL, 2008a).

Recebida a certidão que materializa o inadimplemento, qual é o prazo para o ingresso em juízo com a ação executiva? O STF responde a esta pergunta com a Súmula 150: "Prescreve a execução no mesmo prazo de prescrição da ação". (BRASIL, 1963)

Ressalte-se que apesar de antiga, a Súmula 150 do STF continua atual, na medida em que ainda serve de fundamentação para diversos julgados no Superior Tribunal de Justiça e Tribunal Superior do Trabalho, conforme nos revela estas ementas:

\footnotetext{
Transitada em julgado a ação originária, inicia-se o prazo prescricional para a propositura da respectiva execução, não se aplicando nesse ínterim a prescrição intercorrente prevista no art. $9^{\circ}$ do Decreto 20.910/32. 2. O prazo prescricional da execução é o mesmo da ação originária. Inteligência da Súmula n. ${ }^{\circ} 150$ do Supremo Tribunal Federal. 3. Não transcorrido o lapso prescricional quando da propositura da execução. 4. Recurso especial nãoprovido (BRASIL, STJ. 2 ${ }^{\mathrm{a}}$ Turma. Processo: REsp 961.607/SP. Rel. Min. Mauro Campbell. DJE 01.12.2008. 2008b).

O prazo prescricional da execução de acordo extrajudicial é de dois anos, por aplicação do artigo $7^{\circ}$, inciso XXIX, da CF, e do artigo 11, inciso I, da CLT, e também por aplicação da Súmula 150 do STF [...] (BRASIL, TST. 1 ${ }^{\text {a }}$ Turma. Processo: AIRR-1028540-96.2007.5.09.0009. Rel. Min. Luiz Philippe Vieira de Mello Filho, DEJT 03.09.2010).
}

Sabe-se que, a rigor, a sentença não opera novação, nem cria direitos. É um ato judicial que atua como interruptor da prescrição. Assim sendo, desde o seu trânsito em julgado, em tese, deveria recomeçar a correr o prazo prescricional. No processo do trabalho tal fato inocorre por força do digitado art. 878 da CLT.

Porém, com a novidade da certidão de crédito trabalhista, se o ajuizamento da ação executiva da certidão ocorrer após dois anos de sua expedição pela Vara do Trabalho poderá ser pronunciada a prescrição da pretensão executiva. Isto porque tanto o art. $7^{\circ}$, inciso XXIX da Constituição Federal, quanto o art. 11 da CLT, dispõe que no processo de conhecimento a ação trabalhista prescreve em dois anos. (BRASIL, 2011c)

Ressalte-se que a CLT possui também regramento próprio para tratar da prescrição da pretensão executiva de qualquer dívida de natureza trabalhista. Neste 
sentido, o $\S 1^{\circ}$ do art. 884 estipula que o executado poderá como matéria de defesa na fase de execução alegar o cumprimento da decisão, a quitação ou a prescrição da divida.

Contudo, as normativas pretorianas que criaram a certidão de crédito olvidaramse da possibilidade de decretação da prescrição da pretensão executiva. Prova disto é que expressamente existe a previsão de que a execução da certidão de crédito poderá ocorrer a qualquer tempo, assim que bens do devedor forem encontrados. Neste sentido, oriunda do tribunal pioneiro, a seguinte ementa:

CERTIDÃO DE DÍVIDA TRABALHISTA - PROVIMENTO
GERAL CONSOLIDADO DO TRT $3^{\mathrm{a}}$ REGIÃO - O longo tempo de
paralisação do processo, sem qualquer apresentação pelo credor de meios
passíveis ao prosseguimento da execução, justifica o arquivamento definitivo
do processo (art. $1^{\circ}$, II e $3^{\circ}$ do Prov. 02/2004 da SCR do TRT/ MG), o qual
não implicará qualquer prejuízo, pois o exeqüente poderá promover a
execução de seu crédito tão logo forem encontrados bens do devedor
passíveis de penhora (art. $5^{\circ}$ do Provimento $02 / 2004$ da SCR do TRT/MG).
(MINAS GERAIS, TRT da $3^{\text {a }}$ Região. Processo $\mathrm{n}^{\circ}$ AP-901/2006-058-03-
00.6, Rel. Des. Antônio Álvares da Silva, DEJT 03.12.2010. 2010b).

Conforme se observa, com base nos argumentos expostos, juízes e credores são induzidos ao erro pelas referidas normas. Aqueles ao julgarem com base nas diretivas dos tribunais; estes ao serem induzidos a não se preocuparem com o prazo prescricional. Tais fatos reforçam a constatação do prejuízo que a emissão da certidão de crédito provoca.

\section{PROPOSIÇÕES QUE EVITARIAM A EXPEDIÇÃO DA CERTIDÃO DE CRÉDITO}

Pretende-se demonstrar neste tópico que os juízes do trabalho possuem um cabedal de recursos e ferramentas que o auxiliam na busca da efetividade do processo, sem que tenham que expedir certidão de crédito para findá-lo.

Crê-se que a adoção destas proposições, sempre que necessário, reduzirá o percentual de execuções trabalhistas frustradas, contribuindo para a efetividade material da execução trabalhista, em detrimento da efetividade formal advinda desta invenção dos tribunais, a qual se equivale ao acesso à injustiça.

\subsection{A digitalização dos autos do processo}

Uma das justificativas para a implantação da certidão de crédito é a falta de espaço nas Varas do Trabalho para acomodar o progressivo número de processos físicos. Vislumbrou-se, portanto, que com a expedição da certidão de crédito o 
arquivamento definitivo e consequente descarte dos autos do processo. Deste modo, sobrariam espaço e bens móveis para acolher a gama de novas demandas.

Segundo dados de 2009 do CNJ 33\% do espaço dos tribunais do trabalho são destinados ao arquivo de processos. Isso representa mais de $50 \%$ do espaço útil destinado efetivamente ao trabalho de servidores e magistrados. Se for considerado o espaço necessário para o acesso aos arquivos, este percentual aumentará de forma significativa. (CONSELHO NACIONAL DE JUSTIÇA, 2009).

A solução para este problema é simples. Basta seguir o caminho irreversível do futuro do processo, a sua digitalização. Assim, em vez de se expedir a certidão de crédito, o problema de espaço seria resolvido com a digitalização das principais peças insertas no processo trabalhista, quais sejam, os mesmos documentos que serviriam para instruir a confecção da certidão de crédito.

Neste sentido, com espeque na Lei 11.419/2006, a qual dispõe sobre a informatização do processo judicial, está sendo gestado no âmbito do Conselho Nacional de Justiça e dos tribunais superiores o processo judicial eletrônico, que visa, dentre outros motivos, acabar com o processo físico a fim de convertê-lo em digital.

Com a digitalização indexada de documentos ao processo virtual não haverá mais a necessidade de conservação física do processo, sendo certo que a qualquer momento poderá o feito ser acessado por todos os envolvidos na lide, de qualquer parte do mundo.

Deste modo, seria evitada a expedição da certidão de crédito, bem como haveria a economia de espaço físico nas varas do trabalho, sem prejuízo ao jurisdicionado, que continuaria contando com atuação concorrente e solidária do juiz para a efetividade material da execução, eis que legalmente legitimado para promover a execução de ofício.

\subsection{Do protesto cartorial do título judicial}

Invariavelmente a justificativa dos tribunais do trabalho para a criação da certidão de crédito fundamenta-se na omissão do exequente de não indicar bens do devedor para garantir a execução.

Ainda, como já delineado acima, este argumento não se coaduna com o regramento da CLT, na medida em que o juiz do trabalho é legitimado concorrentemente para promover de ofício a execução trabalhista. 
Prova disto é que o TST, por intermédio da Resolução CGJT N. ${ }^{\circ}$ 001/2011, recomendou que as Corregedorias dos Tribunais Regionais do Trabalho orientassem os juízes da execução a adotarem, de ofício, uma estrutura sequencial de atos nesta fase. Para tanto, foi estabelecida uma ordem cronológica dos eventos processuais a serem praticados antes do arquivamento e emissão da certidão de crédito: Eis a ordem proposta:

a) Citação do executado;

b) Bloqueio de valores do executado via sistema do Bacenjud ${ }^{5}$;

c) Desconsideração da personalidade jurídica da empresa executada;

d) Registro no sistema informatizado e citação do sócio;

e) Pesquisa de bens de todos os corresponsáveis via sistemas Bacenjud, Renajud $^{6}$ e Infojud ${ }^{7}$. (BRASIL, 2011d)

Após a consecução de todos estes atos, e não sendo encontrados bens do executado, recomenda a Corregedoria do Tribunal Superior do Trabalho o arquivamento dos autos do processo e, nada manifestando o autor, a emissão da certidão de crédito.

Ressalte-se que de tal recomendação constava ainda que fosse expedido mandado de protesto extrajudicial. Entretanto, posteriormente, tal comando foi revogado pelo Ato GCCGT 011/2011 (BRASIL, 2011e), tendo por fundamento o fato de que este assunto não está pacificado na doutrina e jurisprudência, razão pela qual não era conveniente a intervenção administrativa da Corregedoria.

Não obstante a esta precaução da Corregedoria do TST, vislumbra-se plenamente aplicável na Justiça do Trabalho o protesto extrajudicial do título de crédito trabalhista no cartório competente, por forma do disposto no art. $1^{\circ}$ da Lei 9.492/97, verbis: “Art. $1^{\circ}$. Protesto é o ato formal e solene pelo qual se prova a inadimplência e o descumprimento de obrigação originada em títulos e outros documentos de dívida" (BRASIL, 1997).

Por força do art. 769 da CLT, temos que tal preceito normativo pode ser aplicado de forma supletiva no processo do trabalho, ampliando o grau de visibilidade da execução corrente.

5 Bacenjud é um instrumento de comunicação eletrônica entre o Poder Judiciário e instituições financeiras bancárias, com intermediação do Banco Central. Por meio dele, os magistrados protocolizam ordens judiciais de requisição de informações, bloqueio, desbloqueio e transferência de valores bloqueados, que serão transmitidas às instituições bancárias para cumprimento e resposta.

6 Renajud é uma ferramenta eletrônica que interliga o Judiciário e o Departamento Nacional de Trânsito Denatran, possibilitando em tempo real a efetivação de ordens judiciais de restrição de veículos cadastrados no Registro Nacional de Veículos Automotores - Renavam.

7 Infojud é um sistema de Informações ao Judiciário que facilita o acesso dos juízes aos dados referentes à renda e ao patrimônio dos réus dos processos judiciais.

Revista da Faculdade Mineira de Direito, v.12, n. 23, jan./jun. 2009 - ISSN 1808-9429. 
A medida, se adotada, será um importante instrumento de coerção indireta do executado ao pagamento da dívida. Com a sua implementação o devedor trabalhista não terá apenas seu patrimônio perseguido pela Justiça do Trabalho. Com o protesto do título executivo judicial serão obstaculizadas as suas relações mercantis, financeiras e comerciais, inclusive com a administração pública, na medida em que não mais conseguirá dos cartórios de protestos a certidão negativa de débito, enquanto não saldar a dívida pendente de quitação junto à Justiça do Trabalho.

Como se observa, a Corregedoria do TST tende a impedir a efetividade da execução, a despeito de a lei que rege a matéria não obstar o uso do protesto cartorial de qualquer documento que represente uma dívida.

Todavia, por se tratar de criticável recomendação, e, por não se tratar de ato normativo vinculante da instância jurisdicional inferior, observa-se que nada impede que os juízes do trabalho implementem, ao final da ordem procedimental sugerida pelo TST, o protesto cartorial da dívida trabalhista, visando possibilitar a entrega do bem da vida ao credor, abreviando, por conseguinte, a duração do processo.

\subsection{Da constatação e penhora nas cooperativas de crédito, corretoras de ações e distribuidoras de títulos}

O CPC dispõe em seu art. 655 que o dinheiro possui preferência sobre todos os demais bens para garantia e quitação da execução. (BRASIL, 2008a).

Para facilitar e otimizar o sistema de pesquisa de ativos financeiros do executado foi criada a ferramenta virtual denominada Bacenjud8. Por intermédio dela, o magistrado emite uma ordem de pesquisa e bloqueio de ativos financeiros do executado. Tal determinação é cumprida pelo Banco Central do Brasil - BC junto a todo o sistema bancário nacional.

Constatada a existência depósitos ou aplicações financeiras em qualquer agência do sistema bancário será procedido ao bloqueio de valores até o limite do valor em execução. O montante bloqueado será imediatamente transferido para uma conta judicial em um banco escolhido pelo magistrado, vinculado aos autos do processo e à disposição do respectivo Juízo.

Apesar do considerável auxílio que a ferramenta Bacenjud propicia ao Judiciário, ela ainda pode ser aperfeiçoada, conforme se constata dos noticiários veiculados da mídia virtual: 
As cooperativas de crédito ainda não estão abrangidas por esse sistema Bacenjud por não terem acesso direto à conta de compensação e reservas bancárias (Compe). [...] É neste momento que surge a divergência, pois enquanto as 150 instituições bancárias do país submetem-se a esse sistema de penhora online dos seus correntistas, as 1.400 cooperativas de crédito existentes não estão abrangidas pelo Bacenjud. (CORRENTISTAS..., 2011)

O Banco Central também estuda uma "fase III" do Bacenjud 2.0, que incluirá a penhora on-line de ativos em cooperativas de créditos, corretoras de ações e distribuidoras de títulos. A mudança deve demorar algum tempo, pois depende da integração do Bacenjud ao Cadastro de Clientes do Sistema Financeiro Nacional (CCS), um banco de dados de todas as contas e ativos registradas no sistema financeiro. [...] O BC recebe 15 mil ordens por dia, enviadas para cerca de 150 instituições. Mas há 1,6 mil cooperativas de crédito e centenas de corretoras e distribuidoras de títulos (BACENJUD..., 2008).

Para confirmar estas constatações, foi realizada uma pesquisa junto ao Departamento de Prevenção a Ilícitos Financeiros e de Atendimento de Demandas de Informações (DECIC) do Banco Central do Brasil, via correio eletrônico, para o endereço bacenjud-ccs@bcb.gov.br, em maio de 2011. Foram formuladas estas perguntas:

a) $\mathrm{O}$ sistema Bacenjud consegue pesquisar/bloquear ativos financeiros depositados em cooperativas de crédito em todo o Brasil?

b) Caso negativo, existe previsão para que todas as cooperativas integrem o sistema Bacenjud? Se positivo, quando?

A resposta encaminhada pelo Banco Central, por intermédio da Subdivisão de Atendimentos a Demandas de Informações (SUADI), ratificou os fatos relatados nas notícias mencionadas da seguinte forma:

\begin{abstract}
As contas mantidas pelas cooperativas de crédito em todo o país que não estejam sob custódia e/ou administração da CEF, Banco do Brasil, Bancos Múltiplos, Bancos com carteira Comercial, Bancos de Investimentos, Bancos de Montadoras, Bancos Estrangeiros com Filiais no País ou Bancos Cooperativos, não são alcançados pelo sistema Bacenjud.

Há estudos técnicos em pauta prevendo a ampliação do alcance do Bacenjud a outras instituições autorizadas pelo Banco Central a funcionar. Mas ainda não há um prazo definido para essa ampliação. (BANCO CENTRAL, 2011, grifou-se).
\end{abstract}

A nosso ver, as cooperativas de crédito, corretora de ações e distribuidora de títulos não podem ficar imunes ao sistema Bacenjud, sob pena de falta de transparência e efetividade desta útil ferramenta. Da forma em que o sistema de bloqueio se encontra, estas instituições estão sofrendo, no mínimo, desvio de sua finalidade, convertendo-se em reduto de maus pagadores, justamente por ficarem imunes à pesquisa do judiciário. 
Deste modo, até que seja atualizada a ferramenta do Bacenjud, seria recomendável que os juízes do trabalho, em vez de emitirem a certidão de crédito, expedissem mandados de constatação e bloqueio de valores para serem cumpridos junto a estas instituições de crédito. Aconselha-se a direcionar os mandados de acordo com a atividade econômica do executado e finalidade da cooperativa. Exemplo: se o executado for uma empresa mercantil a constatação perante as cooperativas de comércio ou múltipla; se for produtor rural, junto às cooperativas de crédito ou produção rural, etc.

Com relação à determinação de constatação de ativos junto às corretoras de ações e distribuidoras de títulos, ela pode ser feita mediante ofício endereçado à Companhia Brasileira de Liquidação e de Custódia - CBLC, empresa associada à Bolsa de Valores de São Paulo - Bovespa, maior instituição brasileira de intermediação para operações no mercado de capitais. Também, o ofício poderá ser encaminhado para o Banco BM\&F, integrante do grupo Bovespa, responsável pela custódia dos ativos de investidores que preferem realizar transações financeiras nos mercados da bolsa sem o suporte de uma corretora de ações ou distribuidora de títulos.

\title{
4.4. Da pesquisa da movimentação de ativos de terceiros (laranjas)
}

Por "laranja" deve se entender o indivíduo, nem sempre ingênuo, cujo nome é utilizado por um terceiro para a prática das mais diversas formas de fraude, operações financeiras e transações comerciais, com a finalidade de escapar do fisco, de aplicar dinheiro originário de atitude ilícita. (FERREIRA, 1986)

Onofre Alves Batista Junior registra o crescimento desta figura na constituição de empresas:

\begin{abstract}
No Brasil vem se alastrando como "erva daninha", a constituição de sociedades em que um sócio se apresenta, "apenas no papel" como minoritário e sem funções gerenciais, e, no entanto, é o verdadeiro gestor e administrador da sociedade, utilizando-se de terceiro para evadir tributos e proporcionar verdadeiros prejuízos ao Erário Público. Trata-se do sabido e consabido uso dos "famosos laranjas", que vêm levando o país à bancarrota, destruindo instituições como a Previdência Social, e porque não até o Erário dos Estados Membros. (BATISTA JÚNIOR, 1999, p. 56).
\end{abstract}

É inegável o uso indevido de laranjas por pessoas que pretendem ocultar patrimônio dos órgãos de fiscalização do Estado e do Poder Judiciário.

Este fato social negativo já foi constatado pelas autoridades brasileiras. Estas, a fim de evitarem que tal prática continue se disseminando, programaram, via Banco Central do Brasil - BC, uma ferramenta que permite pesquisar os dados das pessoas que movimentam ativos financeiros nas instituições, independente de estas serem ou não

Revista da Faculdade Mineira de Direito, v.12, n. 23, jan./jun. 2009 - ISSN 1808-9429. 52 
clientes. Assim, foi desenvolvido o Cadastro de Clientes do Sistema Financeiro Nacional (CCS).

O Cadastro de Clientes do Sistema Financeiro Nacional (CCS) é uma ferramenta virtual que registra as informações relativas a correntistas e clientes de instituições autorizadas a funcionar pelo Banco Central. Dentre as instituições autorizadas incluemse todas as empresas financeiras, de crédito, cobrança, e as administradoras de consórcios, ativos e afins. Está inserido neste cadastro, ainda, o nome de todos os representantes legais ou convencionais dos clientes do sistema financeiro. O cadastro contém dados de pessoas físicas e jurídicas com bens, direitos e valores, bem como de todo relacionamento iniciado a partir 1.1.2001. A partir destes dados é possível saber se é o titular da conta ou terceiro autorizado quem realiza as transações bancárias.

Para subsidiar este artigo, foram colhidas novas informações junto ao Banco Central do Brasil. Este confirmou que pela base de dados do sistema de cadastro mencionado é possível verificar:

a) Os relacionamentos que são mantidos pelas instituições participantes com os seus correntistas e/ou clientes e com os representantes legais e/ou convencionais dos mesmos correntistas e/ou clientes;

b) Os bens, direitos e valores que concretizam tais relacionamentos. (BANCO CENTRAL, 2011).

Vislumbra-se que tal ferramenta é de vital importância para o Poder Judiciário. Com ela é possível descobrir se determinado executado utiliza-se de manobra ardilosa na tentativa de frustrar a execução. Tal ardil ocorre quando o executado movimenta contas correntes ou qualquer ativo financeiro de terceiro (laranja) como representante legal ou convencional deste.

Com tal expediente, nenhuma ordem de bloqueio endereçada ao executado obterá êxito, já que não terá ativo financeiro movimentado em seu nome.

Deste modo, legitimado que está para agir de ofício, sempre que considerar necessário, pode o Juiz ordenar que seja efetuada pesquisa junto ao Cadastro de Clientes do Sistema Financeiro Nacional com o escopo de verificar se o executado movimenta contas/investimentos como procurador legal ou convencional de outros correntistas e/ou clientes.

Caso resulte positiva a pesquisa, o Banco Central do Brasil informará ao juízo a titularidade da conta movimentada pelo executado, a data de início da movimentação, bem como as transações realizadas. Com estes dados, o juiz e/ou a parte interessada 
poderão verificar a relação jurídica entre o executado e o cliente bancário, com o escopo de averiguar possível fraude à execução.

Não é demais afirmar que essa pesquisa se afigurará necessária quando não forem localizados quaisquer bens do executado, após a utilização de todas as ferramentas de pesquisa disponíveis. Tal precaução se impõe por cautela, pois, com ela, o juiz terá maiores elementos para provar que a movimentação financeira de ativos de terceiros pelo executado consiste em uma tentativa de frustrar a execução, já que, não havendo a localização de bens deste e tendo o juiz a ciência de que ele se encontra movimentando contas alheias, pode mais facilmente pressupor a existência de fraude.

Ainda, considerando o exposto no tópico anterior, tal pesquisa poderá ser ampliada para as cooperativas de crédito não integradas ao sistema de dados do Banco Central do Brasil.

Por este prisma, antes de se emitir a certidão de crédito ao exequente, salutar seria que o juiz, de ofício, pesquisasse o uso de "laranjas" pelo executado junto ao sistema bancário, via sistema disponibilizado pelo Banco Central, ou, ainda, caso este resulte inexitoso, via expedição de mandado de constatação perante as cooperativas de crédito, com idêntico intento.

\subsection{Da pesquisa junto às operadoras de cartão de crédito e devedores do executado}

O cartão de crédito é uma forma de pagamento eletrônico. A facilidade de seu uso, aliado à segurança e ampliação da capilaridade de aceitamento deste 'dinheiro de plástico' pelo comércio, inclusive o eletrônico, são alguns dos pontos positivos desta forma de quitação de dívida. O crescimento do uso do cartão de crédito fez decrescer na mesma proporção direta o uso do papel moeda e dos cheques para a quitação de compras e serviços pelos consumidores.

Diante desta realidade, nota-se que o Judiciário utiliza o mandado de penhora na 'boca do caixa' de forma escassa, haja vista a inutilidade de tal procedimento, como consequência da novel forma de quitação das transações de consumo.

Necessário se impõe a adoção de novas técnicas para acompanhar a evolução tecnológica presente na forma de quitação das obrigações. Vislumbra-se como opção de constrição de crédito, em substituição à penhora na "boca do caixa", a possibilidade de expedição de ofício para as operadoras de cartões de crédito. A 'boca do caixa' das empresas não se encontra mais nos estabelecimentos comerciais destas. Na maioria dos 
casos, o caixa de uma empresa executada é o mesmo das inúmeras operadoras de cartões de crédito existentes no País.

Assim o sendo, basta que o juiz oficie as operadoras de cartões de crédito para que estas informem se dada empresa/CNPJ possui contrato e movimentação financeira como credora de dada transação financeira intermediada pela operadora. No mesmo ofício, deve constar que em havendo crédito pendente de quitação para a empresa pesquisada, seja este bloqueado e disponibilizado em uma conta judicial em favor do juízo, na data prevista para a liberação do crédito por parte da operadora.

Sugere-se, ainda, que para evitar burla a esta modalidade de pesquisa de constrição de crédito, o exequente apresente um comprovante de pagamento via cartão de crédito com a empresa executada. A medida proposta se mostra adequada na medida em que a empresa poderá estar utilizando-se de outro CNPJ para realizar as transações com as operadoras de crédito.

Igual medida pode ser adotada junto aos credores do executado, tais como: para as terceirizadas executa-se a medida junto à tomadora dos serviços; pecuarista, junto aos frigoríficos ou laticínios; agricultores, junto aos exportadores ou adquirentes do produto agrícola; as construtoras, junto à administração de obras públicas da União, Distrito Federal, Estados e Municípios.

\section{CONCLUSÃO}

Verificou-se neste artigo que diversos tribunais do trabalho instituíram, cada qual, no âmbito interno de sua jurisdição, a certidão de crédito. Consiste ela em uma nova modalidade de extinção do processo na fase de execução. A busca pela celeridade e efetividade processual, e, principalmente, a pressão exercida pelo CNJ para o cumprimento das metas de desempenho jurisdicional foram os substratos fáticos que motivaram a criação deste título pretoriano.

Procurou demonstrar-se que este artifício procedimental é inconstitucional e duplamente ilegal. A inconstitucionalidade formal consiste na usurpação da competência privativa da União para legislar sobre processo e procedimento. A ilegalidade dúplice foi observada quando se verificou o conflito dos atos internos dos tribunais com o comando do artigo 878 da CLT, e, ainda, a não conformidade destes com os artigos 791, inciso III, 793 e 794 do CPC.

Vislumbrou-se que a certidão de crédito trabalhista propicia a extinção do processo sem que a tutela efetiva tenha sido entregue. Com isso, em termos estatísticos, 
os tribunais que a adotaram parecem efetivos no cumprimento das metas, mesmo não o sendo. Como efeito, tende a alimentar o descrédito na atuação judiciário.

De igual modo, os referidos tribunais operaram grave equívoco ao mencionarem nas normas internas que a certidão de crédito possibilita o ajuizamento de nova ação executiva a qualquer tempo, assim que bens do executado forem encontrados. Tal erro consiste na afronta ao disposto no art. 884 da CLT que trata da prescrição da pretensão executiva. Este artigo interpretado em conformidade com o art. $7^{\circ}$, inciso XXIX da Constituição Federal e com a Súmula 150 do STF revela que a parte exequente terá que ajuizar a ação executiva em dois anos, sob pena de ver pronunciada a prescrição da pretensão executiva.

Como alternativa para se evitar a adoção deste critério pretoriano de extinção processual, propôs-se a adoção de novas técnicas procedimentais para a efetividade da execução trabalhista, tais como a digitalização dos processos cuja execução apresente dificuldade de liquidez; o protesto judicial do título executivo; a expedição de mandados e ofícios para se averiguar a existência de créditos do executado em cooperativas de crédito, corretora de ações, distribuidoras de títulos, operadoras de cartões de crédito e devedores do executado e, ainda, a utilização do Cadastro de Clientes do Sistema Financeiro Nacional - CCS, do Banco Central do Brasil - BC, ferramenta esta que viabiliza a pesquisa do uso de "laranjas" pelo executado junto às instituições bancárias.

Em conclusão, a adoção da certidão de crédito apenas faz com que o processo seja um fim em si mesmo. A insurgência contra a sua expedição se justifica para fazer com que o acesso à justiça se materialize em um procedimento que conheça e declare o direito, e que também o efetive como instrumental necessário para a entrega do bem da vida postulado em juízo. Do contrário, se omissivamente aceitar-se a expedição da certidão de crédito trabalhista, potencialmente poderá ser consolidado o acesso à injustiça.

\begin{abstract}
This academic paper was developed from science creation of praetorian labor credit certificate. It consists in a formal document issued by several labor courts certifying that the person has given credit in a lawsuit, whose execution is ineffective. Delivering the certificate to the creditor that originated the lawsuit it then is finished permanently and the deal resolved. Materializes, so, access to injustice. The doctrine and the academy did not discussed on this topic. This silence is not justified. To break it, we tried to support in the fundamentals of the process, the current legislation and case law. For this, we used arguments that prove the unconstitutionality, illegality and damage that dispatch of
\end{abstract}

Revista da Faculdade Mineira de Direito, v.12, n. 23, jan./jun. 2009 - ISSN 1808-9429. 56 
the credit certificate can generate for the labor creditor. We conclude that its adoption could help to foster distrust of the judiciary together with the labor courts the ability to be applied to forgotten prescription then claim executive in the labor lawsuit. In the end, in a positive way, it presents some viable solutions that would prevent the issuance of the credit certificate and the access to injustice.

Keywords: Labour Courts. Certificate of credit. Illegality.

\section{REFERÊNCIAS}

BACENJUD muda em março. Valor Econômico: Taubaté, 29 fev. 2008. Disponível em: <http://www.oabsp.org.br/subs/taubate/noticias/Valor-Economico-BACEN-JUDMUDA-EM-MARCO>. Acesso em: 04 de jun. 2011.

BANCO CENTRAL Do BRASIL. Informações sobre o Bacenjud. [mensagem pessoal]. Mensagem recebida por: <lamartinooliveira@trt23.jus.br> em 18 mai. 2011.

BARROSO, Luís Roberto. Neoconstitucionalismo e Constitucionalização do Direito: O Triunfo Tardio do Direito Constitucional no Brasil. Revista Brasileira de Direito Público, Belo Horizonte, v. 3, n. 11, out. 2005. Disponível em: <http://bdjur.stj.gov.br/Dspace/handle/2011/18540>. Acesso em: 08 mai. 2011.

BATISTA JÚNIOR, Onofre Alves. Responsabilidade Tributária do Sócio Não Gerente - O "Laranja", A Fraude à Lei e a Desconsideração da Personalidade Jurídica. Revista Jurídica da Procuradoria Geral da Fazenda Estadual de Minas Gerais, n. 35 , jul./set. 1999.

BRASIL. Código de Processo Civil (1973). Organização dos textos, notas remissivas e índices por Nelson Mannrich. 9a ed. São Paulo: Revista dos Tribunais, 2008. 1952 p.

BRASIL. Consolidação das Leis do Trabalho (1943). Organização dos textos, notas remissivas e índices por Armando C. da Costa, Irany Ferrari e Melchíades R. Martins. $38^{a}$ ed. São Paulo: Ltr, 2011c, 976p.

BRASIL. Constituição (1988). Constituição da República Federativa do Brasil. BARROSO, Darlan; JÚNIOR, Marco A. A. (Org.). Vade mecum: especialmente preparado para a OAB e concursos. São Paulo: Editora Revista dos Tribunais, 2011a, p. 59-128.

BRASIL. Constituição (1988) Emenda constitucional n.45, de 30 de dezembro de 2004. Altera dispositivos dos arts. 5 , 36, 52, 92, 93, 95, 98, 99, 102, 103, 104, 105, 107 , 109, 111, 112, 114, 115, 125, 126, 127, 128, 129, 134 e 168 da Constituição Federal, e acrescenta os arts. 103-A, 103B, 111-A e 130-A, e dá outras providências. Diário Oficial da União, Brasília, 31 dez. 2004.

BRASIL. Lei no 6.830, de 22 de setembro de 1980: Dispõe sobre a cobrança judicial da Dívida Ativa da Fazenda Pública, e dá outras providências. Disponível em < http://www.planalto.gov.br/ccivil_03/Leis/L6830.htm> Acesso em: 25 maio. 2011.

BRASIL. Lei no 9.492, de 10 de setembro de 1997: Define competência, regulamenta os serviços concernentes ao protesto de títulos e outros documentos de dívida e dá 
outras providências. 1997. Disponível em

<http://www.planalto.gov.br/ccivil_03/Leis/L9492.htm> Acesso em: 25 maio. 2011.

BRASIL. Lei no 11.419, de 19 de dezembro de 2006: Dispõe sobre a informatização do processo judicial; altera a Lei no 5.869, de 11 de janeiro de 1973 - Código de Processo Civil; e dá outras providências. 2006. Disponível em <http://www.planalto.gov.br/ccivil_03/_ato2004-2006/2006/lei/111419.htm> Acesso em: 25 maio. 2011.

BRASIL. Superior Tribunal de Justiça. Segunda Turma. Processo: REsp 961.607/SP. Rel. Min. Mauro Campbell. Diário da Justiça Eletrônico, Brasília, 01 dez. 2008.

BRASIL. Supremo Tribunal Federal. Súmula no 150, 19 dez. 1963. Imprensa Nacional, 1964, p. 84.

BRASIL. Tribunal Superior do Trabalho. Recomendação CGJT N. 001/2011, da Corregedoria-Geral da Justiça do Trabalho. Diário Eletrônico da Justiça do Trabalho, Brasília, 16 fev. 2011d.

BRASIL. Tribunal Superior do Trabalho. Recomendação CGJT N. ${ }^{\circ}$ 011/2011, da Corregedoria-Geral da Justiça do Trabalho, Diário Eletrônico da Justiça do Trabalho, Brasília, 02 mai. 2011e.

BRASIL. Tribunal Superior do Trabalho. Súmula n 114, 31 out. 1980. Diário da Justiça. Brasília, 03 nov. 1980.

BRASIL. Tribunal Superior do Trabalho. $1^{\text {a }}$ Turma. Processo: AIRR-102854096.2007.5.09.0009. Rel. Min. Luiz Philippe Vieira de Mello Filho, Diário Eletrônico da Justiça do Trabalho, Brasília, 03 set. 2010.

BRASIL. Tribunal Superior do Trabalho. $3^{\text {a }}$ Turma. Processo: AIRR-132001318.2010.5.05.0000. Rel. Min. Alberto Luiz Bresciani de Fontan Pereira. Diário Eletrônico da Justiça do Trabalho, Brasília, 08 abr. 2011b.

CONSELHO NACIONAL DE JUSTIÇA - Justiça em números 2009. Indicadores do Poder Judiciário. Justiça do Trabalho. 2009. Disponível em: <http://www.cnj.jus.br/images/programas/justica-em-numeros/2009/rel-justicatrabalho.pdf> Acesso em: 17 mai. 2011.

CONSELHO NACIONAL DE JUSTIÇA. Metas prioritárias de 2010. Meta 3: reduzir em pelo menos $10 \%$ o acervo de processos na fase de cumprimento ou de execução e, em 20\%, o acervo de execuções fiscais (referência: acervo em 31 de dezembro de 2009). Disponível em: <http://www.cnj.jus.br/gestao-e-planejamento/metas/metasprioritarias-de-2010>. Acesso em: 20 mai. 2011.

CORRENTISTAS utilizam cooperativas para burlar cobrança de dívidas. Informativo Sicoob Central Cecremge. Belo Horizonte, 23 mai. 2011. Disponível em: <http://www.Cecremge.org.br/Notícias/CORRENTISTAS\%20UTILIZAM\%20COOPE RATIVAS\%20PARA\%20BURLAR\%20COBRAN\%C3\%87A\%20DE\%20D\%C3\%8D VIDAS.aspx> Acesso em: 23 DE MAIO DE 2011.

COUTURE, Eduardo J. Estudios de derecho procesal civil. Buenos Aires: Ediar Editores, 1942, T. 1, p. 89.

Revista da Faculdade Mineira de Direito, v.12, n. 23, jan./jun. 2009 - ISSN 1808-9429. 58 
DALAZEN, João Orestes. Discurso proferido na posse do ministro como Presidente do TST. Disponível em:

<http://www.tst.jus.br/ASCS/arquivos/discurso_posse_20110302.pdf.> Acesso em: 06 maio 2011.

EÇA, Vitor Salino de Moura. Cognoscibilidade da prescrição intercorrente no processo do trabalho constitucionalizado. 2008. 207f. Tese (Doutorado) - Pontifícia Universidade Católica de Minas Gerais, Programa de Pós-Graduação em Direito. Belo Horizonte. Disponível em: $<$ http://www.biblioteca.pucminas.br/teses/Direito_ECAVS_1.pdf $>$. Acesso em: 04 jun. 2011.

FERREIRA, Aurélio Buarque de Holanda. Laranja. In: FERREIRA, Aurélio Buarque de Holanda. Laranja. Novo dicionário da língua portuguesa. $2^{a}$ ed. Rio de Janeiro: Nova Fronteira, 1986. p. 676.

KELSEN, Hans. Teoria pura do direito: tradução João Baptista Machado. $6^{a}$ ed. São Paulo: Martins Fontes, 1998. p. 33.

MINAS GERAIS. Tribunal Regional do Trabalho da $3^{\text {a }}$ Região. Provimento $\mathbf{n}^{\mathbf{0}} \mathbf{0 2}$, de 25 de março de 2004. Dispõe sobre o arquivamento definitivo do processo de execução paralisado há mais de um ano nas Varas do Trabalho do Tribunal Regional do Trabalho da $3^{\text {a }}$ Região. Diário da Justiça de Minas Gerais, 31 mar. 2004.

MINAS GERAIS. Tribunal Regional Trabalho da $3^{\text {a }}$ Região. Processo $\mathbf{N}^{\mathbf{0}}$ AP901/2006-058-03-00.6, Rel. Des. Antônio Álvares da Silva. Diário Eletrônico da Justiça do Trabalho, Brasília, 03 dez. 2010.

PONTIFÍCIA UNIVERSIDADE CATÓLICA DE MINAS GERAIS. Pró-Reitoria de Graduação. Sistema de Bibliotecas. Padrão PUC Minas de normalização: normas da ABNT para apresentação de trabalhos científicos, teses, dissertações e monografias / Elaboração Helenice Rêgo dos Santos Cunha. 9. ed. rev. ampl. atual. Belo Horizonte: PUC Minas, 2011.

RENAULT, Luiz Otávio Linhares. Processo, tempo e crédito trabalhista. In: GALUPPO, Marcelo Campos (Org.). O Brasil que queremos reflexões sobre o Estado Democrático de Direito. Belo Horizonte: Editora PUC Minas, 2006, v. 1, p. 445-477. 